IRA-International Journal of Management \&

Social Sciences

ISSN 2455-2267; Vol.13, Issue 02 (November, 2018)

Pg. no. 65-71.

Institute of Research Advances

http://research-advances.org/index.php/RAJMSS

\title{
The Law Related to Consumer Protection in India: Issues and Redressal Mechanism
}

\section{Dr. Sony Kulshrestha}

Associate Professor, School of Law, Manipal University Jaipur, Jaipur, Rajasthan, India.

Type of Review: Peer Reviewed.

DOl: http://dx.doi.org/10.21013/jmss.v13.n2.p4

How to cite this paper:

Kulshrestha, S. (2018). The Law Related to Consumer Protection in India: Issues and Redressal Mechanism. IRA-International Journal of Management \& Social Sciences (ISSN 2455-2267), 13(2), 65-71. doi:http://dx.doi.org/10.21013/jmss.v13.n2.p4

\section{(C) Institute of Research Advances.}

\section{(cc) BY-NO}

This work is licensed under a Creative Commons Attribution-Non Commercial 4.0 International License subject to proper citation to the publication source of the work.

Disclaimer: The scholarly papers as reviewed and published by the Institute of Research Advances (IRA) are the views and opinions of their respective authors and are not the views or opinions of the IRA. The IRA disclaims of any harm or loss caused due to the published content to any party.

Institute of Research Advances is an institutional publisher member of Publishers International Linking Association Inc. (PILA-CrossRef), USA. The institute is an institutional signatory to the Budapest Open Access Initiative, Hungary advocating the open access of scientific and scholarly knowledge. The Institute is a registered content provider under Open Access Initiative Protocol for Metadata Harvesting (OAI-PMH).

The journal is indexed \& included in WorldCat Discovery Service (USA), CrossRef Metadata Search (USA), WorldCat (USA), OCLC (USA), Open J-Gate (India), EZB (Germany) Scilit (Switzerland), Airiti (China), Bielefeld Academic Search Engine (BASE) of Bielefeld University, Germany, PKP Index of Simon Fraser University, Canada. 


\section{ABSTRACT}

Who is a consumer, always creates a new debate? A person who avails/consumes the services in exchange of the consideration is a consumer according to the given definition of consumer under Consumer Protection Act, 1986. This definition never includes any commercial activities or any re-sale or without fee transaction. We on daily basis face various MRP related issues, poor quality of products, adulteration, no bill issues and many more. Some of us raise a voice against these unfair practices but number of us always keep silence and take everything so easy. The reason behind this may be nobody has time or knowledge, when and where to proceed. The right of consumer protection only needs the awareness; awareness about the provisions, process, forums and a fair counselling. Though government has initiated number of awareness schemes which includes the advertisements on television, newspapers and in magazines, skits, workshops and various poster making competitions, still the consumer exploitation continues. In this research paper by using empirical and doctrinal technique of research the researcher wants to highlights the area where the law is lacking its enforcement to protect the interest of consumer. The researcher also draws an attention about the consumer rights, various grievance redressal agencies, who and how can file a complaint, the jurisdiction and the format of filing a complaint.

Keywords: Consumer, Redressal, Forum, Goods, Services and Deficiency.

\section{Introduction}

Generally, buyer and seller of goods are treated to be in position of equality in the eye of law. But in large number of cases, the buyer, by virtue of haste, ignorance, gullibility, inferior bargaining position or simple imprudence, enters into transactions in which the goods supplied or the terms of the contract or both, are unsatisfactory.

In such case the buyer requires special protection as consumer. In civil law relating to sale of goods, the seller is often protected by application of the maxim caveat emptor. Though the buyer has remedy for supply of defective goods, or goods not corresponding to description or sample yet as a consumer has no special remedy under the civil law relating to sale of goods. For that reason, the word "Consumer" has acquired special significance under the law relating to consumer protection. Thus, in the UK the USA, India and other European Countries consumer protection law has received special significance in granting speedy remedies to the consumer.

In India the child going under treatment as well as his parents are consumer. The definition of "Consumer" under section 2(1)(d) of the Consumer Protection Act, 1986 is wide enough to include not only person who hires or avails services, but also beneficiary of such services other than the person who hires or avails services. ${ }^{1}$

In the Unites States the Uniform Commercial Code has softened the rules by providing revocation of acceptance by the buyer under certain circumstances. When goods are accepted, there is a reasonable assumption that the defects in the goods are to be cured. The European Community is also committed to ensure "a high level of consumer protection" and to contribute for protecting "the health, safety and economic interests of consumer".

\section{Some Issues related to Goods or Services Face by the Consumers}

Every person is a consumer in one form or the other. In the free markets, many unfair and unethical tactics are adopted by the producers and sellers and the consumer is very often cheated in the quality, quantity of price of goods and services. Here are some problems faced by the consumers:

1. Adulteration: Malpractice of adulteration is rampant. The innocent consumer is the victim, who has no means to identify the genuine from the adulterated goods.

2. False Weight and Measures: the sellers try to cheat to supply the goods weighing with defective balance and with underweight measures. The consumers go home with less quantity of goods for which they pay the price to a particular measurement.

3. High Price: the sellers release less quantity of goods in market for which there is high demand and they collect higher prices by hiking the prices. Now inflation became a common thing and there is no escape to the consumer except to coexist with it.

\footnotetext{
${ }^{1}$ Spring Meadous Hospital v. Harjol Ahluwalia, AIR 1998 SC 1801.

${ }^{2}$ Article 153 of the EC Treaty.
} 
4. Low Quality Products: The producers bring out goods with quality by reducing their costs and the result is the danger to the consumer.

5. Non-availability of Goods: The short supply of goods leads to non-availability and the consumer has to stand in queues to get the goods he wants.

6. Misleading Advertisements: Numerous deceptive, disruptive and misleading tendencies are followed mainly through advertisement to mould the needs of consumers. Most of the advertisements offering free gifts, high returns for money investments, heavy discounts, announcing nation-wide contest and so on. For a long time, there is no law to control such misrepresentations through advertisements.

Beside above mentioned problems, the black market, unregulated competitions, unfair terms in contract, fraudulent practices, lack of food safety, mal-administration by state, lack of effective remedies and lack of awareness are the other issues. These problems need an effective redressal paradigm and the enactment of Consumer Act is the result of this.

\section{Objects and Reasons for Enactment of Consumer Protection Act, 1986}

The Consumer Protection Act, 1986 seeks to provide for the better protection of the interest of consumers and to achieve that objective it makes provision for the establishment of consumer councils and the authorities for settlement of consumers' disputes and other matters relating thereto. The objects and reasons for passing of the Act are as follows:

a. The rights of consumers are to be protected against marketing of goods which are hazardous to life and property.

b. The rights of consumers are to be informed to them about the quality, quantity, potency, purity, standard and price of the goods against unfair trade practices.

c. The rights are to be assured, wherever possible, access to an authority of goods at competitive prices.

d. The rights are to be heard and to be assured so that the consumers' interests receive due consideration at appropriate forums.

e. The rights for redressal against unfair trade practices or exploitation of consumer are to be provided.

f. The rights to consumer education is also to be provided.

These objects are promoted and protected by the Consumer Protection Council at Centre and State level. To provide speedy and simple redressal to consumer disputes a quasi- judicial machinery has been set-up at the district, State and Central levels. These quasi-judicial bodies will observe the principles of natural justice and they are empowered to give reliefs of specific nature and to award, whenever appropriate, compensations to consumers. Penalties for non-compliance of the orders passed by the quasi-judicial bodies have also been provided.

\section{Constitutional Validity of the Act, 1986}

In State of Karnataka v. Vishwabharathi House Building Co-op. Society ${ }^{3}$, The principle question involved in both of the appeals and the writ petitions was whether the Consumer Protection Act, 1986 is constitutionally valid. In view of the constitutional scheme relating to legislative competence of the Parliament and State Legislature, there cannot be any doubt or dispute that the Parliament has the requisite legislative competence to enact the Consumer Protection Act, 1986. Argument that Parliament did not have competence to create parallel civil court is fallacious inasmuch as the provisions of the said Act are in addition to the provisions of any other law for time-being in force and not in derogation thereof. The said Act supplements and not supplants the jurisdiction of the civil courts or other statutory authorities. After dealing with different provisions of the Act the Supreme Court has held that the Consumer Protection Act, 1986 is constitutionally valid.

\section{Consumer Protection Council}

The Act provides the establishment of the councils at Central, State and District level with the objects of protection of consumers' rights against hazardous goods or services, regarding quality, quantity, potency, standard and price of goods or services, right to be heard and consumer education etc.

\footnotetext{
${ }^{3}$ AIR 2003 SC 1043.
} 
6. Consumer Disputes Redressal Agencies and their Functioning

There are three consumer dispute redressal agencies, a. District Forum b. State Commission and c. National Commission.

6.1 Jurisdiction of the Redressal Agencies: The District Forum shall have jurisdiction to entertain complaints where the value of the goods or services and the compensation, if any, claimed does not exceed rupees twenty lakhs. The State Commission shall have the jurisdiction where the value or compensation exceeds twenty lakh but does not exceed rupees one crore and appeal against the orders of any District Forum within the State.The National Commission having the jurisdiction over the matters exceeding one crore rupees and appeals from State Commissions. The complaint can be instituted within the local limits of whose jurisdiction: the opposite party/ parties at the time of the institution of the complaint, actually and voluntarily resides or carries on business or has a branch office or personally works for gain, or the cause of action wholly or in part arises.

6.2 Manner of Making Complaint ${ }^{4}$ : A complaint in relation to any goods sold or delivered or agreed to be sold or delivered or any service provided or agreed to be provided may be filed with redressal agency by:

- The consumer/ consumers, any recognised consumer association, the Central Government or the State Government as the case may be, either in individual capacity or as a representative of interests of consumer in general.

- Every complaint filed shall be accompanied by the prescribed amount fee.

- The admissibility shall be decided within twenty-one days from the date of filing the complaint after giving the opportunity of hearing to the complainant.

After receiving the complaint, the redressal agency refer a copy of complaint to opposite party directing him to give his version within fifteen days of receiving it.

6.3 Procedure ${ }^{5}$ : The redressal agency shall proceed to settle the consumer dispute in the following manner:

a. Where the complaint alleges defects in the goods, which cannot determine without test, the redressal agency shall obtain a sample, seal it and refer it to the laboratory.

b. Deposition of the prescribed fee by the complainant to carrying out the necessary analysis.

c. If any of the party disputes the correctness of the findings of the laboratory, the redressal agency shall require that party to submit his objection in writing.

d. The redressal agency shall thereafter give a reasonable opportunity to both the parties of being heard and pass appropriate order.

e. The maximum time of redressal is three months from the date of filing of complaint.

f. Appeal ${ }^{6}$ : Order of District Forum $\rightarrow$ State Commission $\rightarrow$ National Commission $\rightarrow$ Supreme Court, within thirty days from such order of any redressal agency.

g. Finality of orders: every order passed by District Forum, State Commission or the National Commission shall, if no appeal is preferred against such order be final.

6.4 Administrative Control: The National Commission shall have administrative control over all the State Commissions in the following matters ${ }^{7}$ :-

a. Calling for periodical returns regarding the institution, disposal or pendency of cases;

b. Issuance of instructions regarding adoption of uniform procedure in the hearing matters, prior service of copies of documents produced by one party to the opposite parties, furnishing of English translation of judgments written in any language, speedy grant of copies of documents;

c. Generally overseeing the functioning of the State Commission or District Fora to ensure that the objects and purposes of the Act are best served without in any way interfering with their quasi-judicial freedom. The State Commission shall have administrative control over all District for a within its jurisdiction in all matters referred to above.

6.5 Limitation Period ${ }^{8}$ : The District Forum, the State Commission or the National Commission shall not admit a complaint unless it is filed within two years from the date on which the cause of action

\footnotetext{
${ }^{4}$ Section 12, Consumer Protection Act, 1986.

${ }^{5}$ Section 13, Consumer Protection Act, 1986.

${ }^{6}$ Sections 15, 19 and 23 respectively of Consumer Protection Act, 1986.

${ }^{7}$ Section 24B, Consumer Protection (Amendment) Act, 1993.
} 
has arisen. A complaint may be entertained after the specified period, if the complainant satisfies the District Forum, the State Commission or the National Commission, as the case may be, that he had sufficient cause for not filing the complaint within such period. But no such complaint shall be entertained unless the National Commission, the State Commission or the District Forum, as the case may be, records its reason for condoning such delay.

6.6 Penalties': Where a trader or a person against whom a complaint is made or the complainant fails or omits to comply with any order made by any redressal agency such trader or person or complainant shall be punishable with imprisonment for a term not less than one month and not more than three years or with fine which may be not less than two thousand rupees but which may be extend to ten thousand rupees or with both.

6.7 Specimen Forms of Complaint before Consumer Redressal Fora:

Complaint before District Consumer Dispute Redressal Forum.

Address

Consumer Complaint No of $20 \ldots$

(Original Jurisdiction)

In the matter of:

A complaint $\mathrm{u} / \mathrm{s} \ldots \ldots . .$. of the Consumer Protection Act, 1986 and the Rules made thereunder And

In the matter of:

A, son of. .residing at

Versus

Complainant

A person, A company. residing at.......or Doing business or having registered office at.... .. within the jurisdiction of Hon'ble Forum

To

Opposite Party

The Hon'ble President and His Companion Members of the District Consumer Redressal Forum.

The complainant above- named most respectfully

\section{SHEWETH:}

1. Description of goods or service: details of place, date, price, deficiency and damage suffered by complainant.

2. Correspondence with opposite party

3. Brief of complaint, evidence in favour, receipt/ guarantee or agreement

4. Relief

Place:

Date:

\section{Verification}

I name, son of...............aged about.....years........profession....., do solemnly declare that the statements made in paragraphs 1 to.... Of the foregoing complaint are true to my knowledge and belief and rest are my submissions to this Hon'ble Forum.

Verified at.

On the day of.....20...

\section{Annexures}

1.

2.

\footnotetext{
${ }^{8}$ Section 24A, Consumer Protection (Amendment) Act, 1986.

${ }^{9}$ Section 27, Consumer Protection Act, 1986.
} 


\section{Defences to Consumer Complaints and Appeals}

There may be general or specific defences to complaint or appeal by consumer before consumer fora. The general defences fall under the headings of i. jurisdiction error, and ii. Bar by limitation. On the other hand, specific defence may relate to i. coverage by definition of the term given in section 2 of the Consumer Protection Act, 1986; ii. Procedural lapses; iii. Non- application of mind to the facts and circumstances of the case; iv. Non-consideration of factors for determining compensation and damages; v. higher rate of interest; vi. Standard of care taken in case of negligence; vii remoteness of damages; and viii. Emotional distress.

\section{Limitation of the Scope of Enforceability of the Act}

Following are not fall in the periphery of the Consumer Protection Act:

1. Those who takes goods or services at free of coast

2. Employers and Employees

3. Matters related to Immovable Property

4. Family Matters

5. Land Lord and Tenant disputes

6. Buyer for commercial purpose, and

7. Contractual obligations

\section{Recent Judgment on Consumer Protection Laws}

Here are some recent judgments of the Supreme Court upon few issues raised in front of it in the appeal from the National Commission:

Chief Administrator, H.U.D.A. \& Anr. v. Shakuntala Devi ${ }^{10}$ in this case the SC held that for entitlement of compensation it is essential to prove loss or damage.

In the case of Om Prakash v. Reliance General Insurance ${ }^{I I}$ the SC held that the Insurance Company cannot reject the claim merely on technical ground, it must be decided on the merits of the case.

In National Insurance Company Ltd. v. Hindustan Safety Glass Works Ltd. \& Anr. ${ }^{12}$ The SC held that the provisions of Limitation Act in Consumer Protection Act cannot be construed to disadvantage to Consumers.

In State of U.P. Through Principal Secretary \& Ors v. All U.P. Consumer Protection Bar Association ${ }^{13}$ In the case, the Supreme Court vide its order in January, 2016 had constituted Committee for examining the aspect of paucity of infrastructure in Consumer Forum and accordingly, the Committee was requested to forward its deliberations to the State Governments.

Later the Supreme Court had issued direction to the Union Government to frame model rules for adoption by the State Governments. The Supreme Court in its latest order has now directed the Union Government to file a comprehensive status report indicating compliance with the directions issued by the Court on affidavit within a period of six weeks.

\section{Conclusion}

Consumer protection laws are designed to ensure fair competition and the free flow of truthful information in the market place. The laws are designed to prevent businesses that engage in fraud or specified unfair practices from gaining an advantage over competitors and may provide additional protection for the weak and those unable to take care of themselves. Consumer Protection is linked to the idea of consumer rights, and to the formation of Consumer Organisations which help consumers make better choices in the marketplace.

The Consumer Protection Act, 1986 has received wide recognition in India as poor man's legislation as it is intended to provide justice which is 'less formal, less paper work, less delay and less expense'. The Act has

\footnotetext{
${ }^{10}(2017) 2$ SCC 301

${ }^{11} 15611$ of 2017

${ }^{12}$ C.A. No. 3883 of 2007

${ }^{13}$ Civil Appeal No. 2740 of 2007
} 
instilled confidence among the 'teeming million' of impoverished litigants. The way in which these cases are being disposed of creates an impression of 'judicial populism' in India in the arena of consumer justice.

\section{References:}

[1]. Dr. S.R. Myneni (2012), Consumer Protection Law, Asia Law House, $1^{\text {st }}$ Edition.

[2]. Aman Chaterjee and Sheetal Shahoo (2011), Consumer Protection: Problem and Prospects in Post Modern openings, Year-2, Vol. 7, September 2011, pp 157-182.

[3]. K. Singh and S. Shetty (2010), Awareness of Consumer Protection Act among Doctors in Udaipur City, India, Journal of Dentistry, Tehran University of Medical Sciences, Vol. 7, No. 1. 2010.

[4]. Majumdar, P.K. (2003), Law of Consumer Protection in India, Prentice Hall of India, New Delhi. 